\title{
A survey of management and economic impact of weeds in dryland cotton cropping systems of subtropical Australia
}

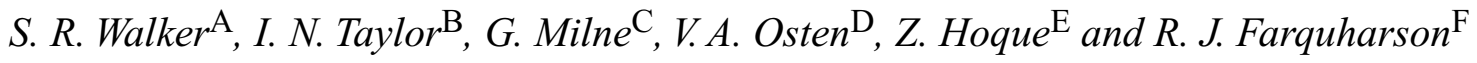 \\ ${ }^{\mathrm{A}} \mathrm{CRC}$ for Australian Weed Management, Department of Primary Industries and Fisheries, \\ PO Box 2282, Toowoomba, Qld 4350, Australia. Corresponding author. Email: Steve.R.Walker@dpi.gov.au \\ ${ }^{B}$ Australian Cotton CRC, Australian Cotton Research Institute, \\ Locked Bag 1000, Narrabri, NSW 2390, Australia. \\ CPO Box 4, Jimbour, Qld 4406, Australia. \\ ${ }^{\mathrm{D}} \mathrm{CRC}$ for Australian Weed Management, Department of Primary Industries and Fisheries, \\ LMB 6, Emerald, Qld 4720, Australia. \\ ENSW Department of Primary Industries, 161 Kite Street, Orange, NSW 2800, Australia. \\ FAustralian Cotton CRC, NSW Department of Primary Industries, \\ RMB 944, Calala Lane, Tamworth, NSW 2340, Australia.
}

\begin{abstract}
In dryland cotton cropping systems, the main weeds and effectiveness of management practices were identified, and the economic impact of weeds was estimated using information collected in a postal and a field survey of Southern Queensland and northern New South Wales. Forty-eight completed questionnaires were returned, and 32 paddocks were monitored in early and late summer for weed species and density. The main problem weeds were bladder ketmia (Hibiscus trionum), common sowthistle (Sonchus oleraceus), barnyard grasses (Echinochloa spp.), liverseed grass (Urochloa panicoides) and black bindweed (Fallopia convolvulus), but the relative importance of these differed with crops, fallows and crop rotations. The weed flora was diverse with 54 genera identified in the field survey. Control of weed growth in rotational crops and fallows depended largely on herbicides, particularly glyphosate in fallow and atrazine in sorghum, although effective control was not consistently achieved. Weed control in dryland cotton involved numerous combinations of selective herbicides, several non-selective herbicides, inter-row cultivation and some manual chipping. Despite this, residual weeds were found at $38-59 \%$ of initial densities in about 3-quarters of the survey paddocks. The on-farm financial costs of weeds ranged from $\$ 148$ to 224/ha.year depending on the rotation, resulting in an estimated annual economic cost of $\$ 19.6$ million. The approach of managing weed populations across the whole cropping system needs wider adoption to reduce the weed pressure in dryland cotton and the economic impact of weeds in the long term. Strategies that optimise herbicide performance and minimise return of weed seed to the soil are needed. Data from the surveys provide direction for research to improve weed management in this cropping system. The economic framework provides a valuable measure of evaluating likely future returns from technologies or weed management improvements.
\end{abstract}

\section{Introduction}

Dryland (rain-grown) cotton has become an important rotational crop during the last 2 decades in the broad-acre cropping region in Southern Queensland and northern New South Wales (NSW). Dryland cotton can account for up to $20 \%$ of the total area sown to cotton in Australia, with the remaining area grown under irrigation (Shaw 2002). The cropping system of dryland cotton is complex, as it involves different rotational crops and variable length fallows, with the amount of stored soil moisture being the most critical factor influencing the decision whether to sow dryland cotton or another crop (Marshall 2002). Dryland cotton is grown in the subtropical region that receives both summer and winter rainfall (Webb et al. 1997) that is variable, particularly during the growing season of summer crops (Hammer and Muchow 1990; Ford and Forrester 2002).

Weed management is, thus, also complex and needs to be flexible to respond to changes in these farming systems (Charles 2002a). Weeds can be very competitive, as cotton seedlings are often slow to emerge and grow slowly in the cool spring conditions. As well, weeds emerge in the nonplanted skip rows and utilise resources that would otherwise be available for cotton plants later in the season. Weeds can be hosts for cotton insects and diseases that adversely affect harvesting and cotton lint quality. In general, weed management in dryland cotton involves controlling weeds in previous fallows and rotational crops using selective herbicides, as well as inter-row cultivation, inter-row 
spraying of non-selective herbicides with a shielded sprayer and manual chipping. However, little information is available on the effectiveness of different weed management practices, the economic impact of weeds or other important weed issues concerning this system. Charles (1991) surveyed weeds in irrigated cotton, which was grown mostly as a mono-culture or in simple crop rotations. The weeds, management techniques and issues are very different between the irrigated and dryland cropping systems.

Several previous surveys documented the weed flora and weed management practices in the grain cropping systems of subtropical Australia. Martin et al. (1988) surveyed the weeds and management practices used in wheat in northern NSW. Later, Felton et al. (1994) surveyed the impact of fallow practices on weed flora in summer fallow and sorghum in the same region. Streit (1996) surveyed the relative importance of the different weed control practices used in the intensive grain-cropping region of the Darling Downs in Southern Queensland. Gavin et al. (1999) monitored changes in weed species, density and effectiveness of control practices in wheat paddocks of a wheat-sorghum rotation in northern NSW and southern Queensland over 2 years. Widderick et al. (1999) conducted a postal survey on distribution and management practices for the control of common sowthistle (Sonchus oleraceus L.) across the subtropical grain region. These field and postal surveys were followed by an extensive postal survey on the distribution and density of weeds in winter crops across Australia, which included northern NSW and Southern Queensland (Jones et al. 2000; Alemseged et al. 2001). These authors validated the postal survey data by following it with a limited field survey.

A few of these weed surveys also estimated the financial and economic impact of weeds in this cropping region. Charles (1991) calculated that the annual costs of weed control in irrigated cotton was $\$ 161 /$ ha for the crop and $\$ 7 /$ ha for the fallow, based on cultivation, herbicides used and chipping. More recently, Jones et al. $(2000,2005)$ calculated that weeds cost $\$ 60 /$ ha for wheat in Southern Queensland and northern NSW, based on weed control expenditure and losses due to residual weeds and contamination.

This paper reports the results from a postal and a field survey of weed diversity and abundance, management practices and their effectiveness, and the estimated financial and economic costs of these weeds in crop rotations with dryland cotton. A distinction is made between the financial and economic costs of weeds. The on-farm or financial costs of weeds arise from both the application of direct control measures and yield losses, whereas the economic costs takes into account the constraint of weeds on aggregate crop production, with potential implications beyond the farm gate for crop processors, manufacturers and consumers. The information is used to provide direction and priorities for research needed to improve weed management, and thus reduce the impact of weeds in this important and relatively new component crop in an inherently complex farming system.

\section{Materials and methods \\ Postal survey}

A self-completion questionnaire was mailed to 286 growers of dryland cotton in Southern Queensland and northern NSW in September 2001. The survey form asked growers to provide information on their crop rotations with dryland cotton, soil types and the use of nominated farming practices for weed control in each crop and fallow and their frequency of use by selecting a category of 'often used', 'sometimes used' or 'rarely or not used'. For each crop and fallow, growers were asked to list the 5 main weeds, herbicides used and control normally achieved by selecting a category of 'very good', 'acceptable' or 'variable'. In addition, they were asked for information on their average crop yields, losses from uncontrolled weeds and contamination penalties. Information from each completed survey was entered into a Microsoft Access database, which was used to collate and present results in this paper. Data are presented as percentages of responses compared with the total number of responses for each part of the questionnaire.

For the most common weeds identified in the postal survey, the proportion of weeds present was examined with the use frequency of each weed control practice used in fallows and the main crops. Weed presence was also compared between Southern Queensland and northern NSW. In addition, the control categories achieved with the different herbicides were compared for the most common weeds. Contingency tables were compiled and were tested for independence using a chi-square test in Genstat (2002).

\section{Grower interview and field survey}

Ten of the postal survey respondents were chosen at random for interviewing and monitoring of weeds in their rotations with dryland cotton. Seven of the farms were located in the Darling Downs region of Southern Queensland, and 3 were located between Goondiwindi and Narrabri in northern NSW.

The growers were asked individually for more information on their crop agronomy and weed management strategies. Then a total of 32 paddocks on these 10 farms were monitored for weed diversity and density. The paddocks were in fallow (19) or in crop with cotton (9) or sorghum (4). Each paddock was rated in December 2001 for weeds initially infesting the crop or fallow and in May 2002 for surviving residual weeds.

Each paddock was divided into 4 sections and 5 transects, each 10 by $1 \mathrm{~m}$, were selected randomly across each section. The presence and density of each weed species were noted in each transect. Species density was rated using the scale $0-3$ : 0 , no weeds $/ 10 \mathrm{~m}^{2} ; 1,1-9$ weeds $/ 10 \mathrm{~m}^{2} ; 2,10-100$ weeds $/ 10 \mathrm{~m}^{2} ; 3,>100$ weeds $/ 10 \mathrm{~m}^{2}$.

\section{Financial and economic analyses}

The cost of weeds that arise from the application of direct control measures and crop yield losses were estimated for each crop and fallow of the rotations in each completed postal survey. This was based on the economic framework described by Jones et al. (2005) that was adapted from McInerney (1996). Weeds have a direct financial impact by either increasing production costs or reducing income through lower yields. The costs of the direct control measures were calculated based on the nominated chemical and non-chemical practices, and their frequency of application for each crop and fallow. The yield losses were calculated based on the growers' estimates of yield loss from their residual weeds and the penalty costs associated with weed contamination, although few growers reported problems of weed contamination in grain or cotton.

The economic analysis was based on the estimated financial costs of weeds and the total crop cost figures from synthetic budgets, using the 
standard industry supply and demand representation, as described by Vere et al. (2002). Economic surplus concepts are widely used in evaluating the social welfare effects of agricultural productivity changes (Alston et al. 1995). The supply and demand functions of a commodity represent its value to producers and consumers. Total economic welfare includes consumer surplus, the difference between the consumer's willingness to pay (demand) and the price, and producer surplus, the difference between price and the marginal costs of production to the producer (supply). The effect of a change in technology is represented in this framework as a shift in the supply function, which interacts with demand to indicate a new equilibrium price and quantity produced, as shown graphically in Vere et al. (2002). The change in economic welfare due to technological improvement can be estimated as a change in total economic surplus, consisting of changes in both consumer and producer surplus. The effect on economic welfare of weeds in dryland cotton crops was evaluated as an inward shift in the industry supply curve from the case of a weed-free environment. Grower estimates of crop yields with and without weeds, together with cotton prices, industry production figures and estimates of demand and supply elasticities were used in the economic analysis. The changes in economic surplus were then calculated using the formulae described by Alston et al. (1995).

Estimates of industry demand and supply elasticities were required for the analysis. Hill et al. (1996) reviewed Marshallian demand elasticities from previous studies and used their own judgment to develop an own-price domestic cotton demand elasticity of -0.2 and a cotton supply elasticity of 1.5 . Clements and Lan (2001) quoted an own-price cotton demand elasticity of -0.14 . Supply elasticities vary according to the length of the run in the decision period, since production responses to price changes are more limited in the short term. Demand for cotton will also vary according to the length of the value chain between producer and consumer. The demand and supply elasticities of -1.5 and 0.8 , respectively, were used in this analysis to estimate the aggregate economic effect of weed costs in dryland cotton. These represented a medium-term case. Two other scenarios with demand and supply elasticities of -0.8 and 0.2 , respectively, and -5.0 and 1.5 , respectively, were tested as shorter- and longer-term cases, respectively.

The costs of the different control practices for various crops in 2000-01 were derived from published gross margin budgets (Scott 2002; Lucy 2002; Lucy et al. 2002). The cotton price of $\$ 525 /$ bale, an Australian price average of the previous 10 years (W. Mollard pers. comm.), was used in the analysis. Estimates of on-farm variable costs and farm-gate prices were also used.

\section{Reliability of survey estimates}

The survey was conducted to find representative information about farmers with cropping systems that included dryland cotton. Errors associated with using a survey estimate to represent a true population parameter include non-sampling and sampling errors. Non-sampling errors can be minimised by careful design and testing of the questionnaire avoiding ambiguous or misleading questions, reducing the possibility of transcription or other processing errors and preliminary data analysis ensuring that the information is derivable.

Standard deviations associated with the mean direct control costs for crops and fallows were estimated, and statistical $t$-tests (Greene 1995 ) were used to signify whether survey means were significantly different from zero.

\section{Results}

\section{Postal survey response}

Forty-eight completed responses were received, representing a response rate of $17 \%$. Thirty-two respondents were from the Darling Downs region and 16 were from the Goondiwindi to Narrabri region. This distribution corresponds well with the proportion of dryland cotton growers in the 2 regions (Cotton Yearbook 2000, 2001, 2002).

\section{Crop rotations and soils}

Twenty-eight crop and fallow sequences with dryland cotton were listed by the growers. The most common rotation was cotton with winter cereal (Table 1). Cotton was rotated with 1 wheat crop (28\%), 2 wheat crops (17\%), 1 wheat crop then 1 barley crop $(5 \%)$ or 3 wheat crops $(1 \%)$. The other common rotation was cotton with summer and winter cereals. In this rotation, cotton was rotated with 1 wheat crop and 1 sorghum crop (11\%) or with 1 wheat crop, 1 barley crop and 1 sorghum crop (4\%). Other rotations were dryland cotton only or were various combinations of sorghum, maize, chickpea, mung bean and peanut crops. Cotton crops were normally preceded by a fallow of about $12-18$ months and were followed with either a winter crop after a very short or 12-month fallow or a summer crop after about a 6-month fallow. Consequently, cotton was grown once every 2-4 years in these rotations. For most interviewed growers, their crop rotation was selected to optimise soil water conservation (90\%) and for better weed control (70\%).

This cropping system was almost entirely grown on Vertosol soils, which have high clay content (40-80\%) with a high capacity to store plant-available water (Webb et al. 1997).

Table 1. Crop rotation category, crops grown with dryland cotton and growers' preference for rotation category (\%) as determined by the postal survey

Growers nominated a total of 79 rotations with 28 different sequences of crops and fallows with most growers nominating more than 1 rotation

\begin{tabular}{llc}
\hline Crop rotation category & Crops grown with dryland cotton & Response (\%) \\
\hline Winter cereal only & Wheat, barley & 51 \\
Summer cereal + winter cereal & Wheat, barley, sorghum & 15 \\
Winter cereal + pulse & Wheat, barley, chickpea, mung bean, peanut & 8 \\
Summer cereal only & Sorghum, maize & 8 \\
Long fallow only & None & 8 \\
Summer cereal + winter cereal + pulse & Sorghum, maize, wheat, barley, chickpea, mung bean & 8 \\
Pulse only & Chickpea, mung bean & 2 \\
\hline
\end{tabular}




\section{Crop agronomy}

The interviewed growers sowed dryland cotton in $1 \mathrm{~m}$ rows as a solid plant, single skip (every third row not planted) or double skip (every third and forth row not planted). The sowing rate of cotton varied from 4.5 to $11 \mathrm{~kg} / \mathrm{ha}$ depending on row spacing. The survey was conducted before the commercial release of Roundup Ready cotton. Sorghum was normally sown in $1 \mathrm{~m}$ rows of either solid planting or single skip at $3-5 \mathrm{~kg} / \mathrm{ha}$. Winter cereals were normally sown in $25-38 \mathrm{~cm}$ rows at $40 \mathrm{~kg} / \mathrm{ha}$ or less.

\section{Fallow weeds}

Growers were highly reliant on knockdown herbicides for fallow weed control with $89 \%$ using these herbicides regularly in both summer and winter fallows (Table 2). Cultivation was used by $23-28 \%$ of growers on a regular basis and another $34-51 \%$ on a less regular basis. Spot spraying and residual herbicides were used regularly by only a few growers, whereas grazing was not commonly used.

Glyphosate alone and glyphosate mixes accounted for the large majority (92-94\%) of the herbicide treatments applied to weeds in fallows (Table 3 ). The most common mix in both fallows was glyphosate with 2,4-D (17\%). In summer fallows, glyphosate was mixed with fluroxypyr, metsulfuronmethyl and atrazine, and to a lesser extent triclopyr, tribenuron-methyl, MCPA and dicamba, whereas in winter fallows it was mixed with metsulfuron-methyl, dicamba and tribenuron-methyl, and to a lesser extent MCPA and oxyflurofen. Several herbicides, not mixed with glyphosate, were applied infrequently, such as metsulfuron-methyl, fluroxypyr, paraquat + diquat and dicamba in summer fallows, and 2,4-D, dicamba and picloram + 2,4-D in winter fallows.

The most common weeds in summer fallows, as nominated by growers, are listed in Table 4. Many growers did not specify the names of their summer grasses, but it is likely that most were referring to barnyard (Echinochloa spp.) and/or liverseed grass (Urochloa panicoides P.Beauv.). These grasses were by far the most common weeds of summer fallows with $82 \%$ of growers listing them as their main weeds. The other common weeds in summer fallows were bladder ketmia (Hibiscus trionum L.), common sowthistle, caltrop (Tribulus spp.), and burrs (Xanthium spp.) and as well as thornapples (Datura spp.), cowvine (Ipomoea lonchophylla J.M.Black) and pigweed (Portulaca oleracea L.). Minor weeds of summer fallows were amaranths (Amaranthus spp.), bellvine (Ipomoea plebia R.Br.), black bindweed (Fallopia convolvulus A. Love), caustic weed (Chamaesyce drummondii D. C. Hassall), devil's claw (Ibicella lutea Lindl. Van Eselt), fleabanes (Conyza spp.), hairy wandering Jew (Commelina benghalensis L.), Johnson grass (Sorghum halepense Pers.), melons (Cucumis spp. and Citrullus spp.), mintweed (Salvia reflexa Hornem.), polymeria (Polymeria pusilla R.Br.), potato weed
Table 2. Management practices and their frequency of use (\%) for weed control in summer and winter fallows, and dryland cotton, sorghum, wheat and chickpea crops as indicated by growers in the postal survey

Values in parentheses are the number of respondents for each fallow and crop

Several growers did not complete all questions on management practices

The late herbicide application was termed 'Late selective herbicide application to control escapes or late flushes'

\begin{tabular}{|c|c|c|c|}
\hline $\begin{array}{l}\text { Management } \\
\text { practice }\end{array}$ & $\begin{array}{c}\text { Often } \\
\text { used }(\%)\end{array}$ & $\begin{array}{c}\text { Sometimes } \\
\text { used }(\%)\end{array}$ & $\begin{array}{c}\text { Rarely or } \\
\text { not used }(\%)\end{array}$ \\
\hline \multicolumn{4}{|c|}{ Summer fallow $(\mathrm{n}=48)$} \\
\hline Knockdown herbicides & 89 & 11 & 0 \\
\hline Cultivation & 28 & 34 & 36 \\
\hline Residual herbicides & 11 & 28 & 51 \\
\hline Spot spraying & 6 & 47 & 28 \\
\hline Grazing & 0 & 11 & 62 \\
\hline \multicolumn{4}{|c|}{ Winter fallow $(\mathrm{n}=48)$} \\
\hline Knockdown herbicides & 89 & 9 & 0 \\
\hline Cultivation & 23 & 51 & 21 \\
\hline Residual herbicides & 11 & 17 & 60 \\
\hline Spot spraying & 6 & 30 & 40 \\
\hline Grazing & 0 & 11 & 62 \\
\hline \multicolumn{4}{|c|}{ Dryland cotton $(\mathrm{n}=48)$} \\
\hline Pre-emergent herbicides & 76 & 15 & 9 \\
\hline Higher seeding rates & 7 & 7 & 70 \\
\hline Post-emergent herbicides & 61 & 28 & 11 \\
\hline Late herbicide application & 20 & 28 & 35 \\
\hline Inter-row cultivation & 52 & 26 & 20 \\
\hline Shielded spraying & 72 & 15 & 7 \\
\hline Chipping & 28 & 52 & 20 \\
\hline Pre-harvest desiccation & 61 & 22 & 11 \\
\hline \multicolumn{4}{|c|}{ Sorghum $(\mathrm{n}=31)$} \\
\hline Pre-emergent herbicides & 68 & 19 & 13 \\
\hline Higher seeding rates & 10 & 16 & 65 \\
\hline Post-emergent herbicides & 45 & 39 & 16 \\
\hline Late herbicide application & 16 & 29 & 45 \\
\hline Inter-row cultivation & 26 & 23 & 48 \\
\hline Shielded spraying & 13 & 35 & 42 \\
\hline Chipping & 0 & 13 & 71 \\
\hline Pre-harvest desiccation & 39 & 39 & 16 \\
\hline \multicolumn{4}{|c|}{ Wheat $(\mathrm{n}=39)$} \\
\hline Pre-emergent herbicides & 18 & 26 & 54 \\
\hline Higher seeding rates & 13 & 28 & 46 \\
\hline Post-emergent herbicides & 56 & 28 & 15 \\
\hline Late herbicide application & 15 & 23 & 54 \\
\hline Inter-row cultivation & 3 & 0 & 74 \\
\hline Shielded spraying & 3 & 0 & 69 \\
\hline Chipping & 0 & 15 & 64 \\
\hline Pre-harvest desiccation & 5 & 3 & 72 \\
\hline \multicolumn{4}{|c|}{ Chickpea $(\mathrm{n}=11)$} \\
\hline Pre-emergent herbicides & 73 & 18 & 9 \\
\hline Higher seeding rates & 0 & 36 & 64 \\
\hline Post-emergent herbicides & 36 & 36 & 27 \\
\hline Late herbicide application & 18 & 9 & 73 \\
\hline Inter-row cultivation & 9 & 18 & 73 \\
\hline Shielded spraying & 0 & 45 & 55 \\
\hline Chipping & 9 & 27 & 55 \\
\hline Pre-harvest desiccation & 55 & 27 & 9 \\
\hline
\end{tabular}


Table 3. Herbicides and their frequency of use (\%) in summer and winter fallows, and cotton, sorghum, wheat and chickpea crops, as indicated by the postal survey

Frequency of use (\%) was determined using the total number of herbicide treatments: summer $(n=177)$ and winter fallows $(n=168)$, cotton $(n=146)$, sorghum $(n=104)$, wheat $(n=121)$ and chickpea crops $(n=34)$

Values in parentheses are the number of respondents for each fallow and crop

\begin{tabular}{|c|c|c|c|}
\hline Herbicide & Usage (\%) & Herbicide & Usage (\%) \\
\hline Summer fallow $(\mathrm{n}=48)$ & & \multicolumn{2}{|l|}{ Sorghum $(\mathrm{n}=31)$} \\
\hline Glyphosate & 55 & Atrazine & 37 \\
\hline Glyphosate + 2,4-D & 17 & Atrazine + fluroxypyr & 24 \\
\hline Glyphosate + fluroxypyr & 8 & Atrazine + metolachlor & 14 \\
\hline Glyphosate + metsulfuron-methyl & 3 & Atrazine + picloram $+2,4-D$ & 4 \\
\hline Glyphosate + atrazine & 2 & Fluroxypyr & 8 \\
\hline Other mixes with glyphosate & 9 & Metolachlor & 7 \\
\hline Other herbicides & 6 & Metolachlor + fluroxypyr & 4 \\
\hline Winter fallow $(\mathrm{n}=48)$ & & Picloram $+2,4-\mathrm{D}$ & 2 \\
\hline Glyphosate & 54 & \multicolumn{2}{|l|}{ Wheat $(\mathrm{n}=39)$} \\
\hline Glyphosate $+2,4-\mathrm{D}$ & 17 & Metsulfuron-methyl + MCPA & 18 \\
\hline Glyphosate + metsulfuron-methyl & 8 & Metsulfuron-methyl & 10 \\
\hline Glyphosate + dicamba & 6 & Metsulfuron-methyl + thifensulfuron & 7 \\
\hline Glyphosate + tribenuron-methyl & 3 & Metsulfuron-methyl + MCPA + Picloram & 4 \\
\hline Other mixes with glyphosate & 4 & $\mathrm{MCPA}+$ picloram & 14 \\
\hline 2,4-D amine & 4 & MCPA & 9 \\
\hline Other herbicides & 4 & MCPA + fluroxypyr & 7 \\
\hline Cotton $(\mathrm{n}=48)$ & & Clodinafop & 12 \\
\hline Glyphosate (shielded sprayer) & 26 & Fenoxaprop & 6 \\
\hline Fluometuron + prometryn & 17 & $2,4-\mathrm{D}$ & 5 \\
\hline Fluometuron + prometryn + pendimethalin & 8 & Dicamba & 3 \\
\hline Fluometuron + prometryn + glyphosate & 6 & Other herbicides & 5 \\
\hline Fluometuron + prometryn + diuron & 3 & \multicolumn{2}{|l|}{ Chickpea $(\mathrm{n}=11)$} \\
\hline Fluometuron + prometryn + diuron + pendimethalin & 3 & Haloxyfop & 24 \\
\hline Fluometuron + prometryn + trifluralin & 3 & Simazine & 15 \\
\hline Pendimethalin & 4 & Simazine + isoxaflutole & 12 \\
\hline Pyrithiobac & 3 & Simazine + prometryn + isoxaflutole & 12 \\
\hline Diuron + prometryn & 3 & Simazine + imazethapyr & 9 \\
\hline Diuron & 3 & Glyphosate with shielded sprayer & 12 \\
\hline Glyphosate + metolachlor & 3 & Other herbicides & 16 \\
\hline Glyphosate + fluroxypyr & 3 & & \\
\hline Other mixes with glyphosate & 2 & & \\
\hline Other herbicides & 13 & & \\
\hline
\end{tabular}

(Galinsoga parviflora Cav.), rhynchosia (Rhynchosia minima DC.), sesbania pea (Sesbania cannabina Pers.), small-flowered mallow (Malva parviflora L.), thistles (possibly Silybum marianum Gaertn. and/or Cirsium vulgare Ten.), turnip weed (Rapistrum rugosum All.), wild oats (Avena spp.), wild gooseberry (Physalis minima L.) and yabila grass (Panicum queenslandicum Domin).

In winter fallows, wild oats, common sowthistle, black bindweed and turnip weed were by far the most common weeds, with half or more of the growers nominating these weeds (Table 4). Paradoxa grass (Phalaris paradoxa L.), wireweed (Polygonum aviculare L.), thistles and mustards (Sisymbrium spp.) were also common but to a lesser extent. Minor weeds of winter fallows were African turnip weed (Sisymbrium thellungii O. E. Schulz), bladder ketmia, caltrop, cowvine, deadnettle (Lamium amplexicaule L.), fleabane, melons, New Zealand spinach (Tetragonia tetragonioides Kintze), potato weed, prickly lettuce (Lactuca serriola L.), ryegrass (Lolium rigidum L.), small-flowered mallow, vetches (Vicia spp.) and wild radish (Raphanus raphanistrum $\mathrm{L}$.).

The majority of growers believed that they achieved very good control of wild oats and paradoxa grass in winter fallow, but less achieved equivalent control for liverseed and barnyard grass in summer fallow (Table 4). The broadleaved weeds, not controlled well by many growers were bladder ketmia, black bindweed and common sowthistle in both fallows.

\section{Weeds in dryland cotton and sorghum crops}

The majority of dryland cotton growers used a mix of weed control practices, such as pre- and post-emergent herbicides, non-selective herbicides applied with a shielded sprayer between the rows, pre-harvest desiccation, inter-row cultivation and, to a lesser extent, chipping (Table 2). Very few growers sowed cotton at higher than district average 
Table 4. The most common weeds (\%) infesting summer and winter fallows, dryland cotton, sorghum, wheat and chickpea crops and their level of control (\%) achieved with herbicides

Values are growers (\%) recording each weed as one of their five main weeds and the control category (\%) nominated for each weed

The number of respondents for each fallow and crop are given in parentheses Several growers listed weeds but did not nominate a control category

\begin{tabular}{|c|c|c|c|c|}
\hline \multirow[t]{2}{*}{ Weed species } & \multirow{2}{*}{$\begin{array}{c}\text { Growers } \\
(\%)\end{array}$} & \multicolumn{3}{|c|}{ Control category $(\%)$} \\
\hline & & Very good & Acceptable & Variable \\
\hline \multicolumn{5}{|c|}{ Summer $(\mathrm{n}=48)$} \\
\hline Grasses & 38 & 83 & 0 & 6 \\
\hline Bladder ketmia (Hibiscus trionum) & 35 & 35 & 29 & 24 \\
\hline Common sowthistle (Sonchus oleraceus) & 31 & 53 & 20 & 0 \\
\hline Caltrops (Tribulus spp.) & 25 & 75 & 17 & 0 \\
\hline Liverseed grass (Urochloa panicoides) & 23 & 55 & 36 & 0 \\
\hline Burrs (Xanthium spp.) & 23 & 73 & 9 & 0 \\
\hline Barnyard grasses (Echinochloa spp.) & 21 & 60 & 20 & 10 \\
\hline Thornapples (Datura spp.) & 19 & 67 & 22 & 0 \\
\hline Cow vine (Ipomoea lonchophylla) & 17 & 75 & 13 & 0 \\
\hline Pigweed (Portulaca oleracea) & 15 & 71 & 29 & 0 \\
\hline \multicolumn{5}{|c|}{ Winter $(\mathrm{n}=48)$} \\
\hline Wild oats (Avena spp.) & 71 & 88 & 6 & 3 \\
\hline Common sowthistle (Sonchus oleraceus) & 65 & 58 & 23 & 13 \\
\hline Black bindweed (Fallopia convolvulus) & 52 & 40 & 24 & 24 \\
\hline Turnip weed (Rapistrum rugosum) & 48 & 74 & 9 & 4 \\
\hline Paradoxa grass (Phalaris paradoxa) & 21 & 100 & 0 & 0 \\
\hline Wireweed (Polygonum aviculare) & 17 & 75 & 0 & 13 \\
\hline Thistles & 17 & 63 & 25 & 13 \\
\hline Mustard or wild turnip & 15 & 100 & 0 & 0 \\
\hline \multicolumn{5}{|c|}{ Cotton $(\mathrm{n}=48)$} \\
\hline Bladder ketmia (Hibiscus trionum) & 46 & 27 & 27 & 30 \\
\hline Caltrops (Tribulus spp.) & 33 & 38 & 25 & 31 \\
\hline Burrs (Xanthium spp.) & 27 & 38 & 23 & 23 \\
\hline Grasses & 23 & 55 & 9 & 18 \\
\hline Liverseed grass (Urochloa panicoides) & 21 & 30 & 20 & 20 \\
\hline Amaranths (Amaranthus spp.) & 21 & 70 & 10 & 0 \\
\hline Barnyard grasses (Echinochloa spp.) & 17 & 38 & 25 & 13 \\
\hline Common sowthistle (Sonchus oleraceus) & 15 & 43 & 43 & 14 \\
\hline Thornapples (Datura spp.) & 10 & 40 & 40 & 0 \\
\hline Cowvine (Ipomoea lonchophylla) & 10 & 60 & 10 & 10 \\
\hline Pigweed (Portulaca oleracea) & 10 & 60 & 0 & 10 \\
\hline \multicolumn{5}{|c|}{ Sorghum $(\mathrm{n}=31)$} \\
\hline Bladder ketmia (Hibiscus trionum) & 45 & 50 & 21 & 14 \\
\hline Caltrops (Tribulus spp.) & 35 & 45 & 36 & 9 \\
\hline Grasses & 29 & 22 & 78 & 0 \\
\hline Thornapples (Datura spp.) & 23 & 71 & 14 & 0 \\
\hline Liverseed grass (Urochloa panicoides) & 23 & 43 & 14 & 29 \\
\hline Amaranths (Amaranthus spp.) & 19 & 86 & 0 & 0 \\
\hline Barnyard grasses (Echinochloa spp.) & 16 & 0 & 40 & 20 \\
\hline Cowvine (Ipomoea lonchophylla) & 13 & 100 & 0 & 0 \\
\hline Burrs (Xanthium spp.) & 13 & 50 & 25 & 0 \\
\hline Pigweed (Portulaca oleracea) & 13 & 75 & 0 & 25 \\
\hline \multicolumn{5}{|c|}{ Wheat $(\mathrm{n}=39)$} \\
\hline Turnip weed (Rapistrum rugosum) & 79 & 84 & 6 & 3 \\
\hline Common sowthistle (Sonchus oleraceus) & 59 & 57 & 30 & 4 \\
\hline Black bindweed (Fallopia convolvulus) & 62 & 33 & 38 & 21 \\
\hline Wild oats (Avena spp.) & 44 & 71 & 12 & 12 \\
\hline Paradoxa grass (Phalaris paradoxa) & 28 & 55 & 27 & 9 \\
\hline Wireweed (Polygonum aviculare) & 28 & 64 & 18 & 18 \\
\hline Mustards (Sisymbrium spp.) & 13 & 60 & 0 & 0 \\
\hline NZ spinach (Tetragonia tetragonioides) & 10 & 75 & 0 & 0 \\
\hline
\end{tabular}


Table 4. Continued

\begin{tabular}{lcccc}
\hline Weed species & Growers & \multicolumn{3}{c}{ Control category (\%) } \\
& $(\%)$ & Very good & Acceptable & Variable \\
\hline & Chickpea $(\mathrm{n}=11)$ & & & \\
Wild oats (Avena spp.) & 82 & 67 & 22 & 11 \\
Turnip weed (Rapistrum rugosum) & 55 & 50 & 17 & 17 \\
Common sowthistle (Sonchus oleraceus) & 55 & 33 & 50 & 0 \\
Black bindweed (Fallopia convolvulus) & 36 & 25 & 50 & 0 \\
Paradoxa grass (Phalaris paradoxa) & 27 & 100 & 0 & 0 \\
\hline
\end{tabular}

seeding rates. In sorghum crops, they used less inter-row cultivation, shielded spraying and chipping.

The most common herbicides used in dryland cotton crops (Table 3) were glyphosate applied with a shielded sprayer $(26 \%)$ and fluometuron + prometryn applied alone or mixed with pendimethalin, glyphosate or diuron $(40 \%)$. The other herbicide treatments listed were diquat + paraquat, diuron, fluazifop, fluroxypyr, haloxyfop, metolachlor, oxyflurofen, pendimethalin, pyrithiobac, trifluralin, triclopyr and various mixes of these herbicides.

Atrazine, alone or mixed, accounted for $79 \%$ of the herbicides used in sorghum crops (Table 3). Fluroxypyr, metolachlor and picloram + 2,4-D were the other herbicides nominated.

The weed flora was very similar in cotton and sorghum crops (Table 4). The most common weeds were bladder ketmia, caltrop, unspecified grasses, liverseed grass and barnyard grass. The burrs were less common in sorghum than cotton crops, and thornapple was more common in sorghum than cotton crops. Other weeds that were listed to a lesser extent were bellvine, black bindweed, black pigweed (Trianthema portulacastrum L.), devil's claw, fleabanes, Johnson grass, melons, mintweed, mustards, paradoxa grass, potato weed, rhynchosia, sesbania pea, summer grass (Digitaria ciliaris Koeler), turnip weed, vetches and wild gooseberry.

The majority of growers did not achieve very good control of many common weeds in both crops, particularly bladder ketmia in cotton and liverseed and barnyard grass in both crops (Table 4). However, amaranths, cowvine and pigweed were generally controlled better than the other common weeds.

\section{Weeds in wheat and chickpea crops}

Weed control in wheat crops relied mostly on postemergent herbicides, with other chemical and non-chemical options used irregularly or rarely by many growers (Table 2 ). In comparison, chickpea growers used more pre-emergent herbicides and pre-harvest desiccation, but tended to use less post-emergent herbicides.

The majority of wheat growers (69\%) applied metsulfuron-methyl, MCPA or mixes with MCPA and/or metsulfuron-methyl (Table 3). Eighteen percent used the graminicides, clodinafop or fenoxaprop. Other herbicides used were 2,4-D, dicamba, and mixes with picloram, thifensulfuron, fluroxypyr and chlorsulfuron. Chickpea growers used mainly the graminicide haloxyfop (24\%), simazine or mixes with simazine (48\%). Others applied glyphosate between rows with a shielded sprayer.

The weed flora in wheat and chickpea crops was very similar, with both crops infested mainly with turnip weed, common sowthistle, black bindweed and wild oats (Table 4). Other weeds included paradoxa grass, wireweed, mustards and New Zealand spinach, and to a lesser extent Mexican poppies (Argemone spp.), prickly lettuce, shepherd's purse (Capsella bursa-pastoris Medik.), thistles and wild radish. The least well-controlled weeds using herbicides were black bindweed in both crops and common sowthistle in chickpea.

Association between main weeds and management practices

There were significant associations or a strong trend for an association between some common weeds and the regular use of various management practices in fallow, dryland cotton and sorghum crops but not in wheat crops. Grasses

Table 5. Weeds proportionally greater in southern Queensland and northern NSW summer and winter fallows, and dryland cotton, sorghum and wheat crops

Values in parentheses are the chi-square probability test of significance

\begin{tabular}{llllll}
\hline Region & Summer fallow & Winter fallow & Dryland cotton & Sorghum & Wheat \\
\hline $\begin{array}{l}\text { Southern } \\
\text { Queensland }\end{array}$ & $\begin{array}{c}\text { Bladder ketmia } \\
(0.019)\end{array}$ & & $\begin{array}{c}\text { Bladder ketmia }(0.001), \\
\text { amaranth }(0.030), \\
\text { caltrop }(0.063)\end{array}$ & $\begin{array}{c}\text { Bladder ketmia } \\
(0.040)\end{array}$ & Barnyard grass $(0.026)$ \\
Northern NSW & Burrs $(0.002)$ & $\begin{array}{c}\text { Paradoxa grass }(0.001), \\
\text { wild oats }(0.022), \\
\text { turnip weed }(0.060)\end{array}$ & & $\begin{array}{c}\text { Wild oats }(0.001), \\
\text { paradoxa grass }(0.001)\end{array}$
\end{tabular}


Table 6. Weed species, paddocks infested and the mean weed density rating in ninteen summer fallow and nine dryland cotton crop paddocks surveyed early (infested) and then late in the season before crop harvest (residual)

Density rating scores, which were given for each weed species detected in 20 by $10 \mathrm{~m}$ quadrats per paddock, were averaged across quadrats and paddocks, using the ratings of 0 , no weeds $/ 10 \mathrm{~m}^{2} ; 1,1-9$ weeds $/ 10 \mathrm{~m}^{2} ; 2,10-100$ plants $/ 10 \mathrm{~m}^{2} ; 3,>100 \mathrm{plants} / \mathrm{m}^{2}$

Dash indicates no weeds were detected

\begin{tabular}{|c|c|c|c|c|c|}
\hline \multirow{3}{*}{ Weed species } & \multirow{3}{*}{$\begin{array}{c}\text { Paddocks } \\
\text { infested } \\
(\%)\end{array}$} & \multicolumn{4}{|c|}{ Mean weed density rating } \\
\hline & & \multicolumn{2}{|c|}{ Fallow } & \multicolumn{2}{|c|}{ Cotton } \\
\hline & & Infested & Residual & Infested & Residual \\
\hline Bladder ketmia (Hibiscus trionum) & 75 & 0.697 & 0.066 & 0.367 & 0.100 \\
\hline Common sowthistle (Sonchus oleraceus) & 54 & 0.105 & 0.150 & 0.194 & 0.139 \\
\hline Pigweed (Portulaca oleracea) & 54 & 0.389 & 0.108 & 0.242 & 0.333 \\
\hline Caltrop (Tribulus spp.) & 43 & 0.095 & 0.034 & 0.044 & 0.028 \\
\hline Dwarf amaranths (Amaranthus macrocarpus) & 43 & 0.139 & 0.021 & 0.133 & 0.050 \\
\hline Barnyard grass (Echinochloa spp.) & 39 & 0.363 & 0.103 & 0.056 & 0.122 \\
\hline Cow vine (Ipomoea lonchophylla) & 36 & 0.232 & 0.016 & 0.061 & 0.044 \\
\hline Australian bindweed (Convolvulus erubescens) & 32 & 0.045 & 0.039 & 0.100 & - \\
\hline Caustic weed (Chamaesyce drummondii) & 32 & 0.075 & 0.029 & 0.056 & 0.078 \\
\hline Liverseed grass (Urochloa panicoides) & 32 & 0.168 & 0.029 & 0.022 & - \\
\hline Boggabri weed (Amaranthus mitchelli) & 25 & 0.087 & 0.008 & 0.106 & 0.006 \\
\hline Malvastrum (Malvastrum americanum) & 25 & 0.037 & 0.013 & 0.011 & - \\
\hline Burr gherkin (Cucumis anguria) & 21 & 0.024 & 0.003 & - & - \\
\hline Fleabane (Conyza bonariensis) & 21 & 0.032 & 0.032 & 0.106 & 0.094 \\
\hline Wild gooseberry (Physalis minima) & 21 & 0.111 & 0.008 & 0.033 & 0.006 \\
\hline Burr medic (Medicago polymorpha) & 18 & 0.013 & 0.003 & 0.017 & - \\
\hline Emu foot (Cullen tenax) & 18 & 0.008 & 0.003 & 0.033 & 0.039 \\
\hline Black bindweed (Fallopia convolvulvus) & 14 & 0.013 & - & 0.006 & - \\
\hline Mintweed (Salvia reflexa) & 14 & 0.047 & 0.016 & 0.006 & 0.033 \\
\hline Redshank (Amaranthus cruentus) & 14 & 0.032 & 0.039 & 0.167 & 0.006 \\
\hline Swamp grass (Paspalidium spp.) & 14 & 0.005 & - & 0.022 & - \\
\hline Yabila grass (Panicum queenslandicum) & 14 & 0.016 & 0.003 & 0.028 & 0.011 \\
\hline Devil's claw (Ibicella lutea) & 11 & 0.008 & - & 0.044 & 0.011 \\
\hline Feathertop Rhodes grass (Chloris gayana) & 11 & 0.005 & 0.003 & 0.006 & - \\
\hline Green amaranthus (Amaranthus viridis) & 11 & 0.082 & - & - & - \\
\hline Native sensitive weed (Neptunia gracilis) & 11 & 0.013 & 0.013 & 0.056 & 0.011 \\
\hline Polymeria (Polymeria pusilla) & 11 & 0.029 & 0.003 & 0.006 & - \\
\hline Rhynchosia (Rhynchosia minima) & 11 & 0.066 & 0.008 & 0.006 & - \\
\hline Turnip weed (Rapistrum rugosum) & 11 & 0.005 & - & 0.006 & - \\
\hline Vigna (Vigna lanceolata) & 11 & 0.005 & - & 0.017 & - \\
\hline Wild oats (Avena spp.) & 11 & 0.066 & 0.011 & - & - \\
\hline Cudweed (Gamochaeta pensylvanica) & 7 & 0.006 & - & - & - \\
\hline Digitaria (Digitaria spp.) & 7 & 0.011 & - & 0.022 & - \\
\hline New Zealand spinach (Tetragonia tetragonioides) & 7 & 0.005 & - & 0.011 & - \\
\hline Panicums (Panicum spp.) & 7 & 0.013 & - & - & - \\
\hline Sesbania (Sesbania cannabina) & 7 & - & - & 0.011 & - \\
\hline Spear thistle (Cirsium vulgare) & 7 & 0.003 & - & 0.006 & - \\
\hline Thornapple (Datura ferox) & 7 & 0.004 & - & - & 0.006 \\
\hline Wireweed (Polygonum aviculare) & 7 & 0.055 & - & - & - \\
\hline African turnip weed (Sisymbrium thellungii) & 4 & - & - & 0.033 & - \\
\hline Black pigweed (Trianthema portulacastrum) & 4 & - & - & 0.011 & 0.006 \\
\hline Blue bells (Wahlenbergia spp.) & 4 & 0.011 & - & - & - \\
\hline Button grass (Dactyloctenium radulans) & 4 & 0.008 & 0.003 & - & 0.044 \\
\hline Chenopodiums (Chenopodium spp.) & 4 & 0.003 & 0.005 & - & 0.006 \\
\hline Cobbler's pegs (Bidens pilosa) & 4 & 0.016 & - & - & - \\
\hline Deadnettle (Lamium amplexicaule) & 4 & - & - & 0.006 & - \\
\hline Docks (Rumex spp.) & 4 & 0.003 & - & - & - \\
\hline Guinea grass (Panicum maximum) & 4 & - & - & 0.006 & - \\
\hline Noogoora burr (Xanthium occidentale) & 4 & 0.003 & - & - & - \\
\hline Paradoxa grass (Phalaris paradoxa) & 4 & 0.003 & - & - & - \\
\hline Prickly lettuce (Lactuca serriola) & 4 & 0.011 & 0.018 & - & - \\
\hline Red flinders grass (Iseilema vaginiflorum) & 4 & 0.003 & - & - & - \\
\hline Slender celery (Ciclospermum leptophyllum) & 4 & 0.003 & - & - & - \\
\hline
\end{tabular}


Table 6. Continued

\begin{tabular}{|c|c|c|c|c|c|}
\hline \multirow[t]{3}{*}{ Weed species } & \multirow{3}{*}{$\begin{array}{l}\text { Paddocks } \\
\text { infested } \\
(\%)\end{array}$} & \multicolumn{4}{|c|}{ Mean weed density rating } \\
\hline & & \multicolumn{2}{|c|}{ Fallow } & \multicolumn{2}{|c|}{ Cotton } \\
\hline & & Infested & Residual & Infested & Residual \\
\hline Small flowered mallow (Malva parviflora) & 4 & 0.003 & - & - & - \\
\hline Stink grass (Eragrostis cilianensis) & 4 & 0.005 & 0.013 & - & - \\
\hline Tree pear (Opuntia monacantha) & 4 & - & - & 0.006 & - \\
\hline Weeping lovegrass (Eragrostis parviflora) & 4 & 0.045 & - & - & - \\
\hline Argentine peppercress (Lepidium bonariense) & 0 & - & 0.003 & - & - \\
\hline Oxalis (Oxalis spp.) & 0 & - & 0.003 & - & - \\
\hline Spiny sida (Sida spinosa) & 0 & - & 0.005 & - & - \\
\hline
\end{tabular}

were associated with growers using residual herbicides in summer fallow $(P=0.060)$. Cowvine $(P=0.038)$ and sowthistle $(P=0.057)$ were spot sprayed in summer and winter fallows, respectively, and amaranth was sprayed late $(P=0.030)$ and with shielded sprayers $(P=0.047)$ in sorghum crops. Caltrop was controlled with tillage in summer fallows $(P=0.046)$ and was inter-row cultivated in dryland cotton crops $(P=0.045)$, whereas black bindweed $(P=0.050)$, turnip weed $(P=0.040)$ and thistles $(P=0.059)$ were cultivated and paradoxa grass $(P=0.037)$ grazed in winter fallow. Amaranth $(P=0.040)$ and thornapple $(P=0.054)$ were associated with growers sowing dryland cotton at higher seeding rates.

There were significant associations or a strong trend for an association between some common weeds and the main herbicides used on these weeds. Bladder ketmia tended to be better controlled with glyphosate mixtures than glyphosate alone in summer fallow $(P=0.071)$, although it was much better controlled in dryland cotton crops with glyphosate than with fluometuron mixtures $(P=0.001)$. Black bindweed tended to be better controlled in winter fallow by glyphosate mixtures than glyphosate alone $(P=0.090)$. Liverseed grass was much better controlled with metolachlor alone or mixtures than with atrazine alone $(P=0.014)$.

\section{Association between main weeds and region}

There were regional differences for some of the common weeds listed in the postal survey (Table 5). Bladder ketmia, amaranth, and, to lesser extent, caltrop were more common in Southern Queensland than in northern NSW. In contrast, burrs and barnyard grass as well as wild oats, paradoxa grass, and, to lesser extent, turnip weed were more common in northern NSW than in Southern Queensland.

\section{Field survey}

In general, the field survey supported the findings of the postal survey in relation to the main weeds and their control during the summer components of the rotations.

Sixty weed species of 54 genera (Table 6), as well as 5 crops, volunteer barley, cotton, sorghum, sunflower and wheat, were identified in the summer fallow and dryland cotton paddocks. The majority of weed species were recorded in the initial survey, whereas 37 weed species were recorded at the end of the season, which were classed as residual weeds.

The most common weed was bladder ketmia, which infested $75 \%$ of the fallow and dryland cotton paddocks (Table 6). The next most common weeds were common sowthistle, pigweed, caltrop (Tribulus spp.), dwarf amaranth (Amaranthus macrocarpus Benth.), barnyard grass (Echinochloa spp.) and cowvine, which were found in $36-54 \%$ of the paddocks. Another 8 species were found in $21-36 \%$ of the paddocks, 6 of which were not nominated as main weeds of summer fallow or dryland cotton by most growers.

Bladder ketmia was by far the most abundant weed infesting summer fallow and dryland cotton when averaged across the surveyed paddocks (Table 6). Pigweed, barnyard grass and cowvine also had high mean density ratings in summer fallow, whereas pigweed and common sowthistle had high mean densities in dryland cotton. Some individual paddocks had very high ratings of 1.7-2.1 for bladder ketmia, pigweed and barnyard grass (data not shown).

The majority of the initially infested paddocks had residual weeds at the end of the crop or fallow (Table 6). The average density ratings of the residual weeds for the 15 most common weeds were 38 and $59 \%$ of the initially recorded levels for summer fallow and dryland cotton, respectively. However, the densities of some weed species increased, particularly common sowthistle in summer fallow, which increased by $43 \%$, and pigweed, barnyard grass and caustic weed in dryland cotton, which increased by $39-118 \%$. In addition, residual densities of fleabane were similar to the initial densities in both situations.

The main weeds in the 4 sorghum paddocks were bladder ketmia, pigweed, barnyard grass and cowvine (data not shown).

\section{Financial and economic impact}

It was estimated from the postal survey that direct weed control costs were $\$ 220 /$ ha for dryland cotton crops compared with $\$ 60 /$ ha for sorghum, $\$ 39 /$ ha for chickpea and $\$ 20 /$ ha of wheat crops, although the estimated weed control costs in wheat and chickpea crops were not significantly 
different from zero (Table 7). They also spent \$34-36/ha on controlling weeds in each 6-month fallow.

Growers estimated that yield losses were about 4-9\% due to competition from residual weeds, resulting in a potential $\$ 18-121 /$ ha loss in production (Table 7). Consequently, the total cost due to weeds was substantial, particularly for dryland cotton, sorghum and chickpea. No sampling errors were calculated for the yield loss estimates as they relied on farmer's perceptions of weed-free crop yields rather than recorded costs. Thus, the sampling errors associated with the total costs of weeds were not derived.

The average total costs of weeds were estimated for the main crop rotations listed in Table 1. Weed control was most expensive when dryland cotton was grown every second summer, and rotated either with wheat (\$224/ha.year) or only fallow (\$223/ha.year). It was least expensive when dryland cotton was grown every forth summer and rotated with 2 wheat crops ( $\$ 148 /$ ha.year) or with a wheat and sorghum crop $(\$ 161 /$ ha.year $)$.

The economic loss in producer surplus associated with weeds in the 69200 ha of dryland cotton in 2000-01 (Cotton Yearbook 2001) was estimated as \$19.6 million per year for the medium-term case scenario. Of this change, $35 \%$ accrued to consumers and $65 \%$ to producers. The estimated losses were $\$ 18.9$ million per year with $20 \%$ for consumers and $80 \%$ for producers, and \$20.6 million per year with $23 \%$ for consumer and $77 \%$ for producer, for the short- and long-term case scenarios, respectively.

\section{Discussion}

Growers nominated 42 different genera as the main weeds of their fallows and crops, including dryland cotton, grown in rotations, which consisted of 28 different crop and fallow sequences, indicating the complexity of weed management in this system. Also, we identified 54 different weed genera in fallows, dryland cotton and sorghum crops during summer 2001-02. The more common weeds identified in the field survey were very similar to those listed as main weeds by the growers, apart from a few weeds, such as thornapple and burrs, which were less common in the field survey. The main problem weeds in the summer components of the rotations were bladder ketmia, common sowthistle, barnyard grass and liverseed grass. Common summer weeds that were not considered by growers as difficult to control included pigweed, amaranths, cowvine and caltrop, although substantial numbers of these weeds were present as residual weeds in dryland cotton crops in the field survey. Black bindweed and common sowthistle were the main winter weeds.

Many growers used a range of selective and non-selective herbicides, and non-chemical tools to control these weeds in dryland cotton crops, indicating that growers are implementing integrated weed management techniques in this crop. However, this strategy was not applied across the farming system, as most growers relied heavily on a limited number of herbicides for weed control in fallows and rotational crops.

The variation in the level of weed management inputs for dryland cotton compared with other crops is shown in the differences in expenditure on weed control. Growers who responded to the postal survey were estimated to spend on average \$220/ha for weed control in dryland cotton crops compared with $\$ 20-60 /$ ha for main rotational crops and \$34-36 for fallows. Despite this large expenditure of \$148-224/ha.year, depending on the rotation, weeds continue to flourish in this cropping system. This is evident by the number of residual weeds in the field survey and the few growers achieving effective herbicidal control of their main weeds in the postal survey.

The approach to weed control requires a change from treating infestations to managing weed populations across the whole cropping system. The aim is to reduce the weed seed-bank with time, as Jones and Medd (1997, 2000) predicted that strategies minimising return of weed seed to the soil maximised profits and reduced the economic impact of weeds in the long term. Weed population management is based on optimal herbicide performance together with additional weed control measures that limits additions to the seed-bank in each component of the rotation. Given that the annual economic costs associated with weeds in dryland cotton crops were estimated to be $\$ 19.6$ million, it is evident that the incorporation of additional and more effective weed control options would be economical in the long term.

Table 7. Estimated direct weed control costs (mean \pm s.d.), yield loss due to uncontrolled weeds including production and cost, and total cost of weeds for summer and winter fallows, and dryland cotton, sorghum, wheat and chickpea crops for the 2000-01 season

\begin{tabular}{lcccc}
\hline $\begin{array}{l}\text { Crop or } \\
\text { fallow }\end{array}$ & $\begin{array}{c}\text { Direct weed control } \\
\text { cost }(\$ / \text { ha) }\end{array}$ & \multicolumn{2}{c}{ Yield loss due to weeds } & $\begin{array}{r}\text { Total cost of } \\
\text { Peeds }(\$ / \text { ha })\end{array}$ \\
\hline Cotton & $220 \pm 62$ & 7.0 & 121 & 341 \\
Sorghum & $60 \pm 27$ & 6.6 & 34 & 93 \\
Wheat & $20 \pm 35$ & 3.7 & 18 & 37 \\
Chickpea & $39 \pm 29$ & 8.6 & 56 & 95 \\
Summer fallow & $36 \pm 10$ & & & \\
Winter fallow & $34 \pm 11$ & & & \\
\hline
\end{tabular}


Several options for better herbicide efficacy were revealed in the survey for key weeds, such as bladder ketmia in fallow and dryland cotton crops, liverseed grass in sorghum crops and black bindweed in fallow. Residual herbicides are often cost-effective weed control options, although the need to maintain flexibility in the cropping system restricts the use of some potentially useful residual herbicides, particularly in fallows and rotational crops (Charles 2002a). The few growers using residuals in summer fallows tended to be targeting annual grasses.

Apart from optimising herbicide performance, other tools need to be incorporated into the management strategy, such as greater crop competition and seed kill techniques that minimise the replenishment of the seed-bank from seeding of weed survivors. Walker et al. $(2001,2002)$ showed that control of wild oats and paradoxa grass was improved substantially with increased competition from winter cereals, and growers in the intensive cropping region of Darling Downs in Southern Queensland considered increasing crop density as an important weed control practice (Streit 1996). In contrast, only a few growers sowed their dryland cotton and rotational crops at higher seeding rates, and this option needs to be explored for summer crops in this environment, and more widely adopted for winter crops of the rotations. Medd et al. (1995) and Cook et al. (1999) developed selective spray-topping technology for seed kill of wild oats and similar techniques may be applicable to surviving summer weeds. Very few growers attempted to control weed survivors or late flushes in the rotational crops, apart from those using spot spraying of thornapple and sowthistle in fallow, and late herbicide application for amaranth in sorghum crops.

Non-chemical weed control options have an important role in population management strategies. A portion of the respondents of the postal survey regularly used tillage for weed control in fallows and summer crops, and chipping for controlling weed survivors in dryland cotton. Tillage tended to target several specific weeds, such as caltrop, black bindweed and turnip weed, although no indication was given on the effectiveness of this tool in preventing weed seed production. Grazing was not used regularly but a few growers occasionally grazed fallows, particularly those containing paradoxa grass. These non-chemical tools are also important in reducing the risk for development of herbicide resistance, which is a major issue for Australian agriculture, although no resistant weeds have been identified in cotton (Charles 2002b). However, several weeds, including wild oats, common sowthistle, black bindweed, turnip weed, mustards, liverseed grass and paradoxa grass, have developed resistance in grain farming systems in the same region (Adkins et al. 1997; Storrie and Walker 1999). Thus, weed management plans in dryland cotton farming systems also need to consider the potential for herbicide resistance.
The main problem weeds in dryland cotton crops differed to those identified by Charles (1991) in irrigated cotton crops. Bladder ketmia was the greatest problem weed identified in our survey, whereas it was ranked sixth in the irrigated cotton survey. Liverseed grass, common sowthistle and amaranths were found in dryland but not in irrigated cotton crops, whereas perennial weeds, such as Cyperus spp., raspweed (Haloragis glauca Lindl.) and polymeria (Polymeria longifolia Lindl.), were major weeds of irrigated cotton crops but were not identified in our survey.

In this survey, the weed flora and their relative importance in summer fallow and sorghum crops were similar to those reported by Felton et al. (1994) in the wheat-sorghum cropping system of northern NSW. The main exceptions were the lesser importance of bladder ketmia and the absence of cowvine in their survey. The main weeds found in wheat crops were similar to those recorded in other surveys conducted during the last 2 decades (Martin et al. 1988; Gavin et al. 1999; Alemseged et al. 2001) and included wild oats, paradoxa grass, 1 or more Brassicaceae weeds and wireweed, with most surveys also recording common sowthistle and black bindweed. Differences were the increasing importance of common sowthistle over time, as found by Widderick et al. (1999), and the absence of annual ryegrass (Lolium spp.) in our survey compared with the survey by Alemseged et al. (2001) in which it was an important weed. The relative importance of the Brassicaceae weeds also differed between the surveys, for example wild turnip (Brassica tournefortii Gouan.), was ranked second in the survey by Alemseged et al. (2001), but was not mentioned as a main weed in the other surveys. This may be due to incorrect weed identification as many of the Brassicaceae weeds are commonly referred to as turnip weed or wild turnip.

The use of surveys and the interpretation of survey results seem relatively widespread, but seldom is there any acknowledgement of the possibility, or implications, of sampling errors associated with these types of analyses. Straight comparisons of estimates derived from survey processes may lead to invalid conclusions. The standard errors associated with the direct weed control costs in this survey were quite large, particularly for the main crops rotated with dryland cotton. This indicates that there was a considerable amount of variation in weed control practices used in these crops. As well as sampling errors, there are likely to be substantial non-sampling errors associated with the use of self-administered surveys and response bias.

The estimated weed control costs in dryland cotton cropping systems are large compared with total costs, indicating that there is scope for gains from improved weed management across the rotation. The aggregated estimates of financial and economic costs associated with current weed infestations in dryland cotton cropping systems were also substantial, although not as large as the $\$ 151.7$ million estimated for wheat in grain cropping systems in the same 
region (Jones et al. 2005). This is due at least partly to the much larger area of wheat sown in southern Queensland and northern NSW compared with dryland cotton.

The financial estimates are derived by applying an estimated per ha cost to a fixed area of production. The economic analysis, characterising the costs associated with weeds impacting on aggregate supply, is a normative analysis, which assumes a supply response to the additional costs. Intuitively, it is expected that the economic could outweigh the financial effects because off-farm effects are included in the former. The economic cost estimated here relates to total weed costs. By itself, this figure is not very useful in a research and development (R\&D) priority-setting context because it is unlikely that all weed costs can be mitigated. However, the estimation framework itself can be used to evaluate potential payoffs from particular R\&D proposals, a substantial advantage from using the economic framework. Several potential R\&D projects could be analysed using this framework to provide a ranking according to likely net benefits. Where relevant, changes in potential crop yield losses associated with different technologies should be included in the R\&D evaluations. This framework also allows an allocation of benefits between producers, processors and consumers both domestic and export, which can have implications with regard to who should fund the research. Such analyses would need to consider assumptions about patterns and rates of technology adoption by industry.

Response rate to the postal survey was similar to that of other surveys (Alemseged et al. 2001). The questionnaire requested detailed information on many aspects of weed management, and this may have contributed to the reduced response rate. However, sufficient information was obtained from the postal and field surveys to benchmark the weed situation in dryland cotton cropping systems, and to identify and prioritise research needs for improved weed management.

\section{Acknowledgments}

We thank all of the participating growers, especially the 10 who volunteered to be interviewed and have their paddocks closely scrutinised. The professional assistance and technical support from Michael Widderick and Anne Sullivan were greatly appreciated. Assistance in economic analysis from B. McCorkell and Randall Jones is also much appreciated. This research was funded by Cotton Research and Development Corporation (CRDC), Grains Research and Development Corporation (GRDC), Cooperative Research Centre (CRC) for Australian Weed Management and Australian Cotton CRC.

\section{References}

Adkins SW, Wills D, Boersma M, Walker SR, Robinson G, McLeod RJ, Einam JP (1997) Weeds resistant to chlorsulfuron and atrazine from the north-east grain region of Australia. Weed Research 37, 343-349. doi:10.1046/J.1365-3180.1997.D01-56.X
Alemseged Y, Jones RE, Medd RW (2001) A farmer survey of weed management and herbicide resistance problems of winter crops of Australia. Plant Protection Quarterly 16, 21-25.

Alston JM, Norton GW, Pardey PG (1995) 'Science under scarcity: principles and practice for agricultural research evaluation and priority setting.' (Cornell University Press: Ithaca)

Charles G (2002a) Weed management. In 'Australian dryland cotton production guide'. (Ed. R Schulze) pp. 53-62. (Cotton Research and Development Corporation: Narrabri, NSW)

Charles G (2002b) Managing herbicide resistance in cotton. In 'Weedpak - a guide for integrated management of weeds in cotton'. (Ed. S Johnson) pp. C2.1-C2.6. (Australian Cotton Cooperative Research Centre: Narrabri)

Charles GW (1991) A grower survey of weeds and herbicide use in the New South Wales cotton industry. Australian Journal of Experimental Agriculture 31, 387-392.

Clements KW, Lan Y (2001) World fibres demand. Journal of Agricultural and Applied Economics 33, 1-23.

Cook A, Storrie A, Medd R (1999) Selective spray-topping: field testing of a new technique for reducing wild oat seed production. In 'Proceedings of the 12th Australian weeds conference'. (Eds AC Bishop, M Boersma, CD Barnes) pp. 31-34. (Tasmanian Weed Society: Hobart)

Cotton Yearbook (2000) 1999-2000 cotton season. In 'Cotton yearbook 2000'. (Ed. D Dowling) pp. 4-5. (The Australian Cottongrower: Toowoomba, Q1d)

Cotton Yearbook (2001) 2000-2001 cotton season. In 'Cotton yearbook 2001'. (Ed. D Dowling) pp. 4-5. (The Australian Cottongrower: Toowoomba, Q1d)

Cotton Yearbook (2002) 2001-2002 cotton season. In 'Cotton yearbook 2002'. (Ed. D Dowling) pp. 4-5. (The Australian Cottongrower: Toowoomba, Q1d)

Felton WL, Wicks GA, Welsby SM (1994) A survey of fallow practices and weed floras in wheat stubble and grain sorghum in northern New South Wales. Australian Journal of Experimental Agriculture 34, 229-236.

Ford B, Forrester N (2002) Impact of rainfall variability. In 'Australian dryland cotton production guide'. (Ed. R Schulze) pp. 13-15. (Cotton Research and Development Corporation: Narrabri, NSW)

Gavin JJ, Rew LJ, Medd RW, Robinson GR, Walker SR (1999) On farm monitoring of weed occurrence and density in the northern grain region. In ' Proccedings of the 12th Australian weeds conference'. (Eds AC bishop, M Boersma, CD Barnes) pp. 31-34. (Tasmanian Weed Society: Hobart)

Genstat (2002) 'Genstat release 6.1.' (VSN International Ltd: Oxford)

Greene WH (1995) 'Econometric analysis.' 2nd edn. (Macmillan Publishing Company: New York)

Hammer GL, Muchow RC (1990) Quantifying climatic risk to sorghum in Australia's semiarid tropics and subtropics: model development and simulation. In 'Climatic risk in crop production: models and management for the semiarid tropics and subtropics'. (Eds R Muchow, J Bellamy) pp. 205-232. (CAB International: Wallingford, UK)

Hill DJ, Piggott RR, Griffith GR (1996) Profitability of incremental expenditure on fibre promotion. Australian Journal of Agricultural Economics 40, 151-174.

Jones R, Alemseged Y, Medd R, Vere D (2000) The distribution, density and economic impact of weeds in the Australian annual winter cropping system. CRC for Weed Management Systems, Technical Series No. 4, Adelaide.

Jones RE, Medd RW (1997) Economic analysis of integrated management of wild oats involving fallow, herbicide and crop rotational options. Australian Journal of Experimental Agriculture 37, 683-691. doi:10.1071/EA97036 
Jones RE, Medd RW (2000) Economic thresholds and the case for longer term approaches to population management of weeds. Weed Technology 14, 337-350.

Jones RE, Vere DT, Alemseged Y, Medd RW (2005) Estimating the economic costs of weeds in Australian annual winter crops. Agricultural Economics (in press).

Lucy M (2002) 'Crop management notes.' Summer 2002 edn. (CD-ROM) (Queensland Department of Primary Industries: Brisbane)

Lucy M, French V, Bullen K (2002) 'The new crop management notes.' Queensland winter edn 2002-2004. (CD-ROM) (Queensland Department of Primary Industries: Brisbane)

McInerney J (1996) Old economics for new problems - livestock disease. Journal of Agricultural Economics 47, 295-314.

Marshall J (2002) Fallow management and crop rotations. In 'Australian dryland cotton production guide'. (Ed. R Schulze) pp. 35-40. (Cotton Research and Development Corporation: Narrabri, NSW)

Martin RJ, McMillan MG, Cook JB (1988) Survey of farm management practices of the northern wheat belt of New South Wales. Australian Journal of Experimental Agriculture 28, 499-509.

Medd RW, Nicol HI, Cook AS (1995) Seed kill and its role in weed management systems: a case study of seed production, seed banks and population growth of Avena species (wild oats). In 'Proceedings of the 9th EWRS symposium. Challenges for weed science in a changing Europe'. pp. 627-632. (European Weed Research Society: Budapest, Hungry)

Scott F (2002) Crop economics. In 'Australian dryland cotton production guide'. (Ed. R Schulze) pp. 19-32. (Cotton Research and Development Corporation: Narrabri, NSW)

Shaw G (2002) Introduction. In 'Australian dryland cotton production guide'. (Ed. R Schulze) pp. 1-3. (Cotton Research and Development Corporation: Narrabri, NSW)

Storrie A, Walker S (1999) Coping with the threat of resistance in weeds. In 'Proceedings of the 2 nd national conservation farming and minimum tillage conference'. (Ed. M Burgis) pp. 39-42. (Conservation Farmers Inc.: Toowoomba, Qld)
Streit L (1996) Perceptions and attitudes towards integrated weed management in the intensive broadacre cropping region of the Darling Downs in southern Queensland. In 'Proceedings of the 11th Australian weeds conference'. (Ed. RCH Sheppard) pp. 39-41. (Weed Science Society of Victoria: Frankston, Vic.)

Vere DT, Jones RE, Dowling PM, Kemp DR (2002) Economic impact of Vulpia in temperate pasture systems in south-eastern Australia. Australian Journal of Experimental Agriculture 42, 465-472. doi:10.1071/EA01100

Walker SR, Medd RW, Robinson GR, Cullis BR (2002) Improved management of Avena ludoviciana and Phalaris paradoxa with more densely sown wheat and less herbicide. Weed Research $\mathbf{4 2}$, 257-270.

Walker SR, Robinson GR, Medd RW (2001) Management of Avena ludoviciana and Phalaris paradoxa with barley and less herbicide in subtropical Australia. Australian Journal of Experimental Agriculture 41, 1179-1185. doi:10.1071/EA01002

Webb AA, Grundy MJ, Powell B, Littleboy M (1997) The Australian sub-tropical cereal belt: soils, climate and agriculture. In 'Sustainable crop production in the sub-tropics an Australian perspective'. (Eds A Clarke, P Wylie) pp. 8-23. (Queensland Department of Primary Industries: Brisbane)

Widderick M, Sindel B, Walker S (1999) Distribution, importance and management of Sonchus oleraceus (common sowthistle) in the northern cropping region of Australia. In 'Proceedings of the 12th Australian weeds conference'. (Eds AC Bishop, M Boersma, CD Barnes) p. 198. (Tasmanian Weed Society: Hobart)

Received 19 September 2003, accepted 10 May 2004 